\title{
THE EFFECT OF EXPOSURE TO SEISMIC PROSPECTING ON CORAL REEF FISHES
}

\author{
Walter A. Boeger ${ }^{1,2^{*}}$, Marcio R. Pie ${ }^{1,2}$, Antonio Ostrensky ${ }^{2,3} \&$ Marcelo F. Cardoso ${ }^{2,3}$ \\ ${ }^{1}$ Universidade Federal do Paraná - Departamento de Zoologia \\ ${ }^{2}$ Grupo Integrado de Aqüicultura e Estudos Ambientais \\ ${ }^{3}$ Departamento de Zootecnia \\ (Caixa Postal 19073, 81531-990, Curitiba, PR, Brazil) \\ *wboeger@ufpr.br
}

Effective management of marine environments requires an understanding of how natural communities are affected by anthropogenic perturbations. A potentially severe stress to these environments is the seismic prospecting of hydrocarbon deposits (Gausland, 2003). This method is based on the production of high intensity sound pulses, which are reflected by the ocean floor and recorded using very sensitive hydrophones. After being processed, these signals are used by researchers to generate a wealth of information about the topography of the ocean floor and its underlying geological formations. Given that the use of air guns is currently the most important method of seismic prospecting (Wardle et al., 2001; Gausland, 2003), several studies have investigated the environmental impact of the use of air guns, particularly on shrimp fisheries (Andriguetto-Filho et al., 2005), marine turtles (McCauley et al., 2000), and mammals (Richardson et al., 1986; Au et al., 1997; Richardson \& Wursig, 1997; Goold \& Fish, 1998; Gordon et al., 1998; McCauley, 1998; Schlundt et al., 2000; McCauley \& Duncan, 2001). Relatively few studies have been conducted on fish, focusing mostly on how seismic prospecting affects fish abundance (e.g. Dalen \& Knutsen, 1987; Skalski et al., 1992; Pickett et al., 1994; Engås et al., 1996, Hassel et al., 2004, Slotte et al., 2004). Little is known about the acute effects of exposure to air guns on fish (Popper, 2003). Santulli et al. (1999) found evidence of biochemical stress responses of the European sea bass (Dicentrarchus labrax; Linnaeus, 1758) after exposure to seismic prospecting, with stress hormones returning to normal levels within $72 \mathrm{~h}$ after exposure. However, a field study by McCauley et al. (2003) showed that the ears of fish exposed to an operating air-gun sustained extensive damage to their sensory epithelia that was apparent as ablated hair cells, with no evidence of repair or replacement of the damaged sensory cells up to 58 days after air-gun exposure. On the other hand, Popper et al. (2005) found little impact of exposure to a $730 \mathrm{in}^{3}$ air gun array on hearing of three fish species. Further experiments on different ocean conditions and with different species are thus necessary to reach a consensus regarding the deleterious effects of seismic prospecting on marine fish. In the present study we conducted a series of observations of coral reef fish in field enclosures before, during and after exposure to air guns to assess how they are affected by this disturbance.

Experiments were carried out near the islands of Tinharé and Boipeba, State of Bahia, Brazil $\left(13^{\circ} 33^{\prime} 43.5^{\prime} \mathrm{S}-38^{\circ} 48^{\prime} 59.9^{\prime \prime} \mathrm{W}\right)$ using an array of 8 synchronized air guns, each with 10.41 (635 cu.in.) of total capacity, supply pressure of $136 \mathrm{~kg} / \mathrm{cm}^{3}(2.000$ psi), and generated sound peak pressure of $196 \mathrm{~dB}$ (re $1 \mu \mathrm{Pa}$ ref $1 \mathrm{~m}$ ), kept at a depth of $5 \mathrm{~m}$. Sound levels were measured using a 24bit recording system (Model Geode) attached to hydrophones which were lowered into the sea from a local vessel. After being collected in situ using purse seine, specimens were transferred to net pens $(2 \times 2 \times 1.20 \mathrm{~m})$. The pens were made of open PVC tubing, so that the water could flow inside to prevent the presence of air within them, thus preventing alterations in the sound field. The fish were fed pieces of shrimp and fish twice a day until being transferred to the experimental cage $(1 \times 1 \times 0.7 \mathrm{~m}$, Fig. 1) $1 \mathrm{~h}$ before the beginning of each experiment (except for experiment 3 , in which case the fish were transferred $24 \mathrm{~h}$ prior to the experiment). Two video cameras (Aqua-Vu, ZT series, Nature Vision Inc.) placed on opposite sides of the cage recorded continuously the behavior of the enclosed fish 5-15 min before, during, and $5 \mathrm{~min}$ after exposure to air guns (Fig. 1). Divers checked the experimental cages immediately before each experiment.

Three different experimental configurations were used (Table 1), varying the number and identity of the fish species, the depth of the experimental cage and the distance from the air guns. In the second configuration, an individual of Lutjanus synagris showed clear evidence of poor health indicated by erratic and unbalanced swimming behavior. We decided to keep this individual during the experiment nevertheless, since its compromised health might cause it to be more susceptible to disturbance from air guns, therefore providing a slightly more conservative assessment. 


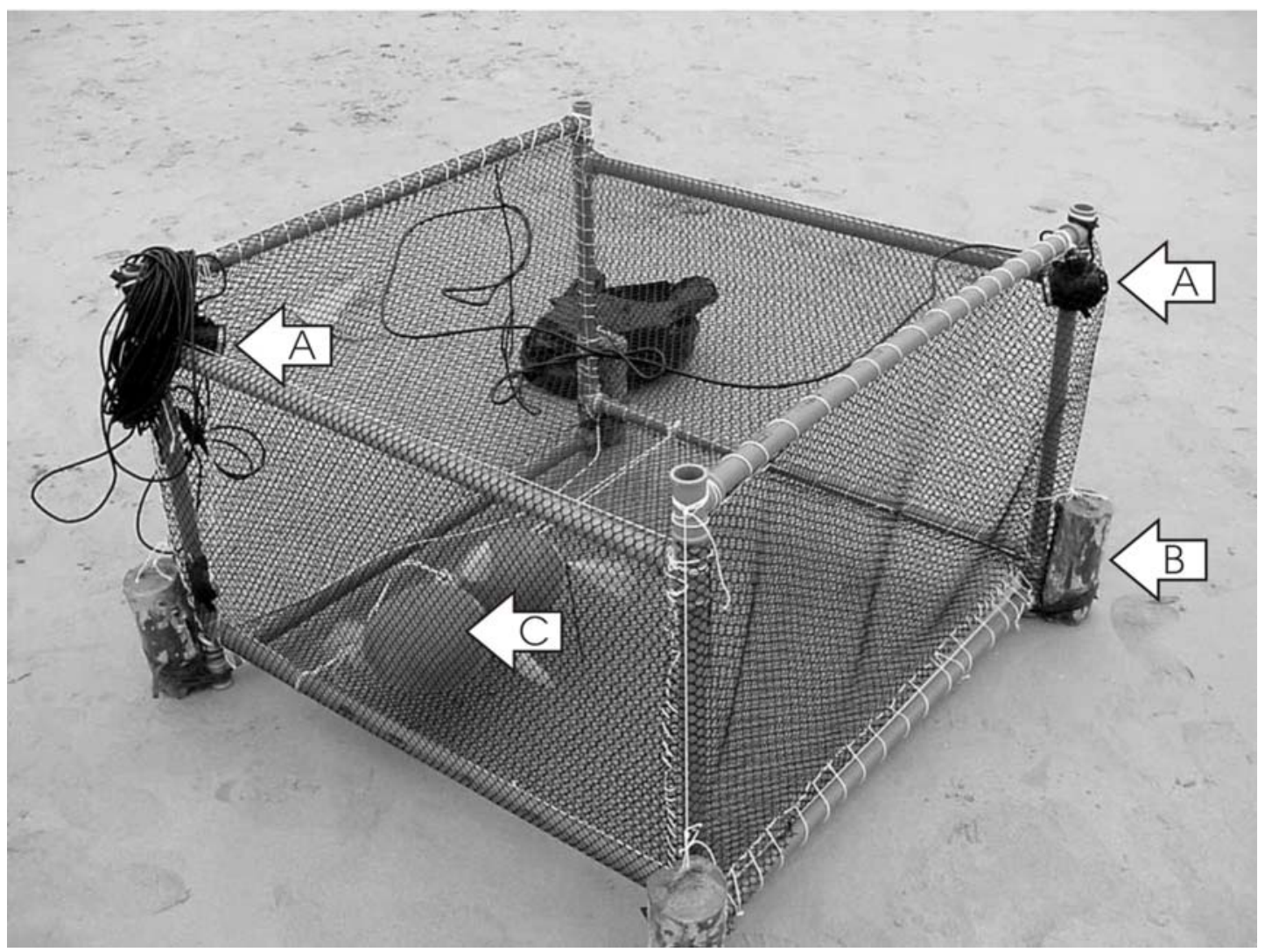

Fig. 1. Experimental cage used in this study. A:. Position of the video cameras. B.. Weights to stabilize the cage. C:. Balloons were placed inside the cage to facilitate the detection of the time of air-gun shot.

Table 1. Description of the experimental configurations used in this study to evaluate the effect of exposure to air guns on three species of marine fish [Lutjanus synagris (Linnaeus, 1758), Chaetodipterus faber (Broussonet, 1782), Lutjanus apodus (Walbaum, 1792)]. See text for details. Configuration 3 was conducted using 2 air-guns (2.29 bar at one meter/air gun).

\begin{tabular}{|c|c|c|c|}
\hline & Configuration 1 & Configuration 2 & Configuration 3 \\
\hline \multirow[t]{2}{*}{ Fish composition } & 5 Lutjanus synagris & 4 Lutjanus synagri & 6 Lutjanus synagris \\
\hline & 3 Chaetodipterus faber & 1 Lutjanus apodus & 6 Chaetodipterus faber \\
\hline Fish sizes & $15-35 \mathrm{~cm}$ & $15-20 \mathrm{~cm}$ & $10-25 \mathrm{~cm}$ \\
\hline $\begin{array}{l}\text { Depth of cage in the water } \\
\text { column }\end{array}$ & $5 \mathrm{~m}$ & $7.5 \mathrm{~m}$ & $5 \mathrm{~m}$ \\
\hline $\begin{array}{l}\text { Horizontal distance } \\
\text { from air guns }\end{array}$ & $7 \mathrm{~m}$ & $0 \mathrm{~m}$ & $1 \mathrm{~m}$ \\
\hline $\begin{array}{c}\text { Depth at the } \\
\text { experimental site }\end{array}$ & $50-60 \mathrm{~m}$ & $7.5 \mathrm{~m}$ & $60 \mathrm{~m}$ \\
\hline Exposure regime & $\begin{array}{c}2 \text { passes } \\
\text { of the gun boat }\end{array}$ & $\begin{array}{c}2 \text { passes } \\
\text { of the air boat }\end{array}$ & $\begin{array}{c}50 \text { blasts of } \\
\text { static air guns }\end{array}$ \\
\hline
\end{tabular}


Despite the relatively severe conditions, our experiments did not result in mortality or obvious external damage in any experimental configuration, including the case of the L. synagris specimen that had poor health at the beginning of the experiment. Rather, the vast majority of air gun shots resulted in a startle
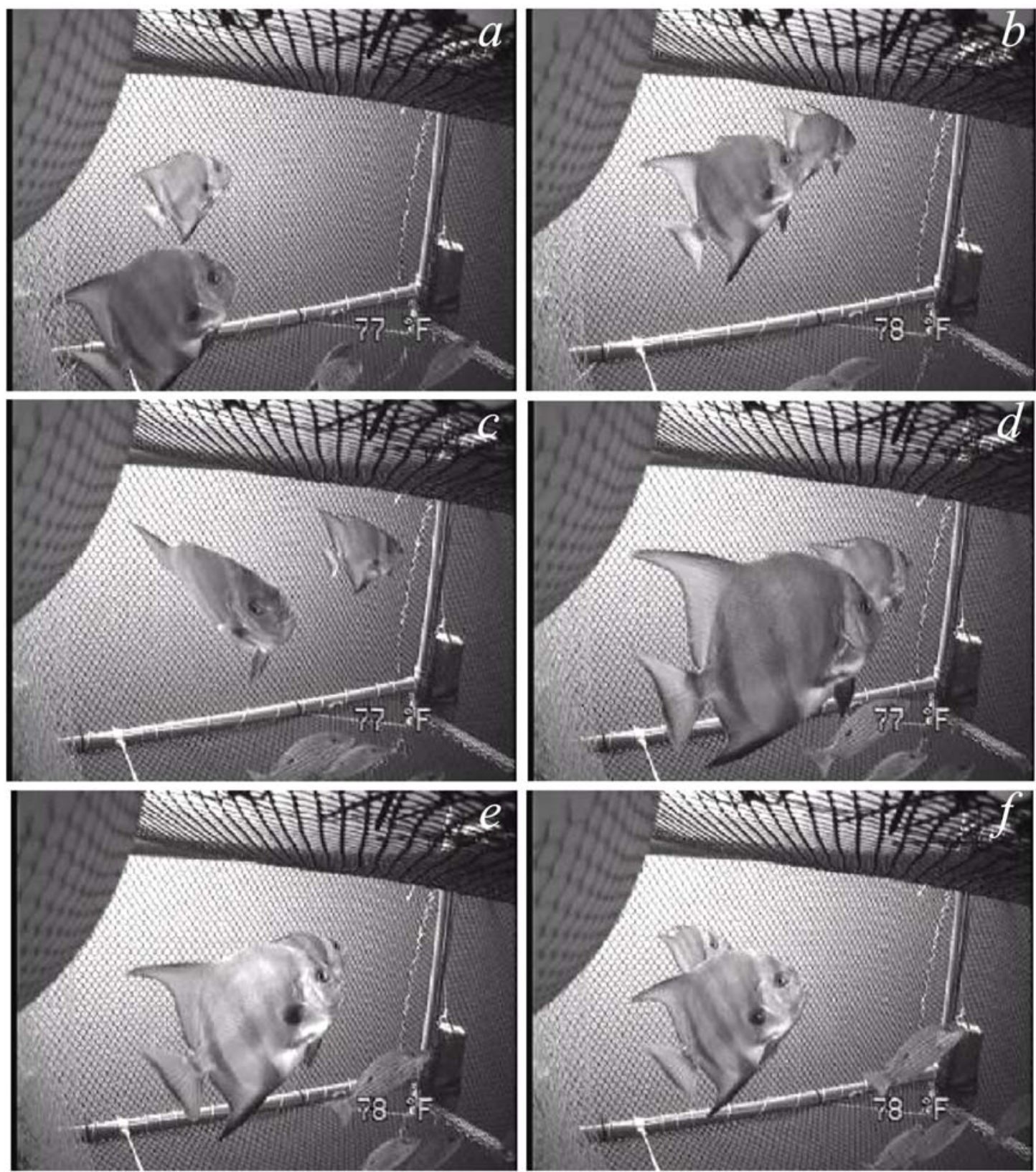

Fig. 2. Plate with a sequence of 6 snapshots describing c-start reflex in Chaetodipterus faber. Time between frames is approximately $0.5 \mathrm{~s}$. Notice that the reflex is not shown by Lutjanus synagris. response in the form of a temporary increase in swimming velocity and/or a lateral shift in swimming direction, returning to normal swimming velocities shortly thereafter (Fig. 2). Moreover, repeated exposure to air guns seemed to result in increasingly less obvious startle responses, indicating possible
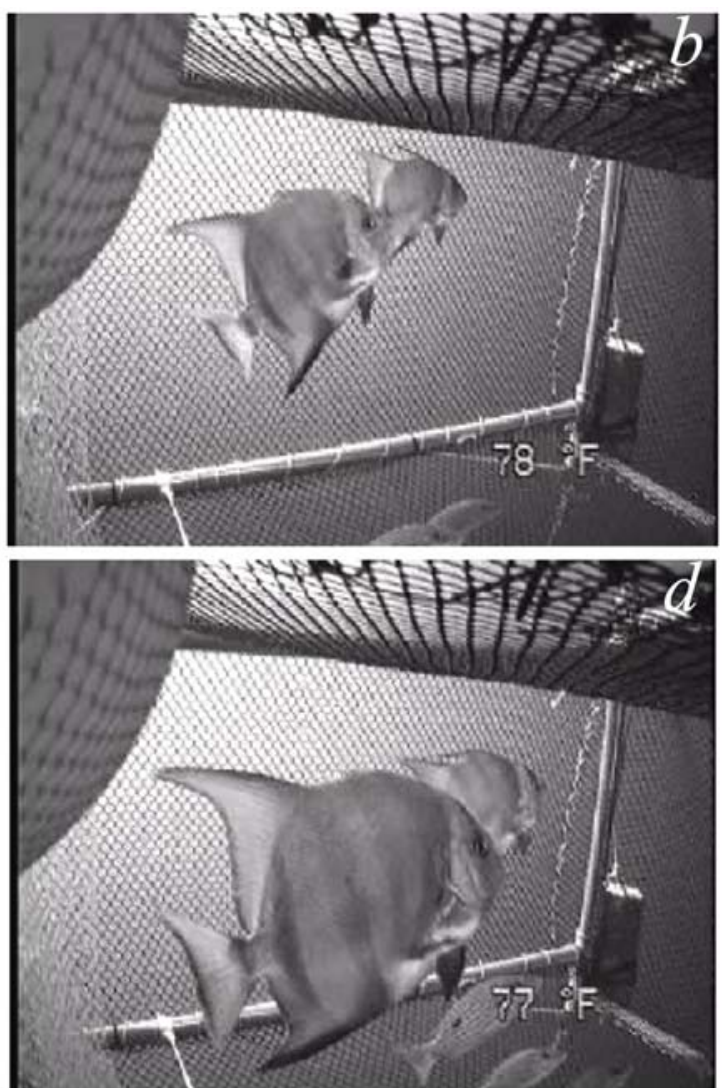
habituation to the disturbance. Our results are consistent with previous experiments under different conditions. Wardle et al. (2001) exposed marine fish to pressure levels between 210 and $218 \mathrm{~dB}$ (re $1 \mu \mathrm{Pa}$ ref $1 \mathrm{~m}$ ) produced using a triple $\mathrm{G}$. air gun and detected little effect on the "day-to-day" behavior of resident reef fish, despite the fact that specimens were not restricted inside field enclosures and could potentially swim away. We did not observe other behavioral changes such as milling or moving to the bottom of the cage (Pearson et al., 1992). Mauthner cell reflex (C-start reflex, Wardle et al., 2001) was observed occasionally, but it was not a consistent response among individuals or species for individual shots. In the second experiment, the field of view of one of the cameras also allowed the observation of the behavior of fishes outside the experimental cage, which departed immediately after the air gun started shooting. Therefore, evasion from the site where seismic prospecting is being conducted might further minimize the impact of air gun exposure on fish health.

In conclusion, exposure to air guns at the levels used in our experiments did not cause immediate fish mortality nor obvious short-term deleterious effects, as has been observed in other studies (e.g. Hassel et al., 2004). These results do not rule out possible physiological effects (e.g. Santulli et al., 1999). Even though the noise levels in our experiments are comparable to those routinely used in shallow water near-shore prospecting sites, future studies using much higher levels such as those used in deep ocean prospecting would be particularly revealing.

\section{Acknowledgments}

We thank Grant Geophysical, especially D. Matos and D. Araújo for logistic and operational support for this work. Invaluable field assistance was provided by our field personnel (R. T. Vianna, N. Sponholz) including the crew of Renasceu (Mundinho, Gerinho, Babau and Gaúcho) and by J. A. Duarte from the Instituto Brasileiro do Meio Ambiente. L. A. Pereira and R. W. Pilchowski provided laboratory support.

\section{REFERENCES}

Andriguetto-Filho, J. M.; Ostrensky, A.; Pie, M. R.; Silva, U. A. \& Boeger, W. A. 2005. Evaluating the impact of seismic prospecting on artisanal shrimp fisheries. Continent. Shelf Res., 25:1720-1727.

Au, W. L. L.; Nachtigall, P. E. \& Pawloski, J. L. 1997. Acoustic effects of the ATOC signal $(75 \mathrm{~Hz}, 195 \mathrm{~dB})$ on dolphins and whales. J. acoust. Soc. Am., 101:29732977.

Dalen, J. \& Knutsen, G. M. 1987. Scaring effects in fish and harmful effects on eggs, larvae and fry by offshore seismic explorations. In: Merklinger, H. M. ed. Progress in Underwater Acoustics. New York: Plenum Publishing Co.:93-102.

Engås, A.; Løkkeborg, S.; Ona, E. \& Soldal, A. V. 1996. Effects of seismic shooting on local abundance and catch rates of cod (Gadus morhua) and haddock (Melanogrammus aeglefinus) Can. J. Fish. aquat. Sci., 53:2238-2249.

Gausland, I. 2003. Impact of seismic surveys on marine life. In: SPE International Conference in Health, Safety and the Environment in Oil and Gas Exploration and Production. June 2000, Stavanger, Norway, Society of Petroleum Engineers., p.. 26-28 .

Goold, J. C. \& Fish, P. J. 1998. Broadband spectra of seismic survey air-gun emissions, with reference to dolphin auditory thresholds. J. acoust. Soc. Am., 103:2177-2184.

Gordon, J. C. D.; Gillespie, D.; Potter, J.; Frantzis, A.; Simmonds, M. \& Swift, R. 1998. The effects of seismic surveys on marine mammals. In: Proceedings of the UK Seismic and Marine Mammals Workshop. London, p. 23-25.

Hassel, A.; Knutsen, T.; Dalen, J.; Skaar, K.; Løkkeborg, S.; Misund, O. A.; Ostensen, O.; Fonn, M. \& Haugland, E. K., 2004. Influence of seismic shooting on the lesser sandeel (Ammodytes marinus). ICES J. mar. Sci. 61: 1165-1173.

McCauley, R. D. 1998. Radiated underwater noise measured from the drilling rig Ocean General, rig tenders Pacific Ariki and Pacific Frontier, fishing vessel Reef Venture and natural sources in the Timor Sea, Northern Australia. Centre Marina Science \& Techology Report.

McCauley, R. D. \& Duncan, A. J. 2001. Marine acoustic effects study, blue whale feeding aggregations, Otway Basin, Bass Strait Victoria. Unpublished report to Ecos Consulting, Australia.

McCauley, R. D.; Fewtrell, J.; Duncan, A. J.; Jenner, C.; Jenner, M.-N.; Penrose, J. D.; Prince, R. I. T.; Adhitya, A.; Murdoch, J. \& McCabe, K. 2000. Marine seismic surveys a study of environmental implications. APPEA J., 40:692-708.

McCauley, R. D.; Fewtrell, J. \& Popper, A. N. 2003. High intensity anthropogenic sound damages fish ears. J. acoust. Soc. Am., 113:638-642.

Pearson, W. H.; Skalski, J. R. \& Malme, C. I. 1992. Effects of sounds from a geophysical survey device on behavior of captive rockfish (Sebastes spp.). Can. J. Fish. aquat. Sci., 49:1343-1356.

Picket, G. D.; Eaton, D. R.; Seaby, R. M. H. \& Arnold, G. P. 1994. Results of bass tagging in Poole Bay during 1992.. Lowestof, Ministry of Agriculture, Fisheries and Food, Directorate of Fisheries Research, Laboratory Leaflet 74.

Popper, A. N. 2003. Effects of anthropogenic sounds on fishes. Fisheries, 28:24-31.

Popper, A. N.; Smith, M. E.; Cott, P. A.; Hanna, B. W.; MacGillivray, A. O.; Austin, M. E. \& Mann, D. A. 2005. Effects of exposure to seismic airgun use on hearing of three fish species. J. acoustic. Soc. Am., 117:3958-3971. 
Richardson, W. J. \& Wursig, B. 1997. Influences of man-made noise and other human actions on cetacean behaviour. Mar. freshwat. Behav. Physiol., 29:183-209.

Richardson, W. J.; Wursig, B. \& Greene Jr., C. R. 1986. Reactions of bowhead whales, Balaena mysticetus, to seismic exploration in the Canadian Beaufort Sea. J. acoustic. Soc. Am., 79:1117-1128.

Santulli, A.; Modica, A.; Messina, C.; Ceffa, L.; Curatolo, A.; Rivas, G.; Fabi, G. \& D'Amelio, V., 1999. Biochemical responses of European sea bass (Dicentrarchus labrax L.) to the stress induced by off shore experimental seismic prospecting. Mar. Pollut. Bull., 38:1105-1114.

Schlundt, C. E.; Finneran, J. J.; Carder, D. A. \& Ridgway, S

H. 2000. Temporary shift in masked hearing thresholds of bottlenose dolphins, Tursiops truncatus, and white whales, Delphinapterus leucas, after exposure to intense tones. J. acoust. Soc. Am., 107:3496-3508.

Skalski, J. R.; Pearson, W. H. \& Malme, C. I. 1992. Effects of sounds from a geophysical survey device on catchper-unit-effort in a hook-and-line fishery for rockfish (Sebastes spp.), Can. J. Fish. aquat. Sci., 49:1357-1365.
Slotte, A.; Hansen, K.; Dalen, J. \& Ona, E. 2004. Acoustic mapping of pelagic fish distribution and abundance in relation to a seismic shooting area off the Norwegian west coast. Fish. Res. 67:143-150.

Wardle, C. S.; Carter, T. J.; Urquhart, G. G.; Johnstone, A. D. F.; Ziolkowski, A. M.; Hampson, G. \& Mackie, D. 2001. Effects of seismic air guns on marine fish. Continent. Shelf Res., 21:1005-1027.

(Manuscript received 22 November 2005; revised 06 March 2006; accepted 06 September 2006) 